\title{
Eri detektiomenetelmien soveltuvuus navetan pintojen puhtauden seurantaan
}

\author{
Risto Kuisma, Hanna-Riitta Kymäläinen \\ Helsingin yliopisto, maataloustieteet, PL 28 (Koetilantie 5), 00014 Helsingin yliopisto, \\ risto.kuisma@helsinki.fi,hanna-riitta.kymalainen@helsinki.fi
}

Navetoille ovat tyypillistä eri hygieniatasojen huonetilat, joiden välinen ristikontaminaatio voi tuoda hygieniaongelmia. Kotieläinrakennusten hygieniaa on tutkittu aiemmin lukuisilla mikrobiologisilla, biokemiallisilla, kemiallisilla, fysikaalisilla ja visuaalisilla menetelmillä, mutta kattavaa detektiomenetelmien vertailua ei ollut löydettävissä. Tuotantotilojen pintahygienian seuranta on olennainen omavalvonnan osa elintarviketuotannossa. Aiemmin tehdyssä hygieniakartoituksessa kartoitettiin navetan huonetilojen hygieniaa. Tässä laboratoriotutkimuksessa haluttiin selvittää, miten eri mikrobiologiset ja yleiset hygieniatestit soveltuvat navetan likojen mittaamiseen. Tutkittaviksi valittiin teräspinnat, joita on navetoissa esimerkiksi altaissa ja maitosäiliöissä. Pinnat liattiin seitsemällä erilaisella navettaympäristön mallilialla, joita olivat neljä eri rehua, kuivike, lanta ja maito. Pinnan puhtaus mitattiin pinnan likauksen ja puhdistuksen jälkeen erilaisilla mikrobiologisilla kontaktilevyillä, proteiinitesteillä, glukoosi- ja laktoositestillä sekä ATP-bioluminesenssimenetelmällä (ATP = adenosiinitrifosfaatti). Tulokset kerättiin tiedostoon ja luokiteltiin puhtausluokkiin. Mikrobeja todettiin kaikilla muilla lioilla paitsi maidolla liatulta pinnalta. Sokereita todettiin vain kahdella rehulla liatulta pinnalta. Proteiinitesti reagoi kaikkiin muihin likoihin paitsi kuivikkeeseen, ja ATP:tä todettiin kaikilta pinnoilta. Selvin korrelaatio havaittiin kolmen proteiinitestin tulosten välillä ( $r$-arvot vaihtelivat 0,62 ja 0,89 välillä, $p<0,001$ ). Korrelaatiota ei todettu aerobisten mikrobien sekä proteiinitestin ja ATP-bioluminesenssimittauksen tulosten välillä (rarvot vaihtelivat 0,09 ja 0,47 välillä, $\mathrm{p}<0,001$ ). Hyvin likaiset pinnat eivät sovellu mikrobiologisille kontaktilevyille, joiden tuloksen saamiseen kuluu myös enemmän aikaa kuin muilla tutkituilla menetelmillä. Rinnakkaismittaukset ovat suuren hajonnan vuoksi tarpeen. ATP-bioluminesenssi on hyvin herkkä menetelmä. Navettaliat reagoivat rajoitetusti sokeritestiin. Lian värillisyys tulee ottaa huomioon esimerkiksi proteiinitestien käytössä. Näytteenottokohteet tulee suunnitella huolella. Tulosten arviointi ja luokittelu ovat olennainen osa tulosten tulkintaa. Navettaympäristön hygieniaan ei ole olemassa yleisiä raja-arvoja. Tutkimuksen tuloksia voidaan hyödyntää valittaessa sopivia hygienian mittausmenetelmiä navettaympäristöön.

Avainsanat: navetta, hygienia, mittaaminen

\section{Johdanto}

Navetoille ovat tyypillisiä eri hygieniatasojen huonetilat. Yleisimmät lian lähteet navetoissa ovat rehut, kuivikkeet, lietelanta, virtsa, maito ja vesi. Navetan pintojen hygieniatasolla on suuri merkitys, koska pintojen likaisuus voi vaikuttaa maidon laatuun (De Koning ym. 2003, Hanus ym. 2004, Skrzypek 2006, Trevisi ym. 2006, DeVries ym. 2012), eläinten terveyteen (Noordhuizen ja Cannas da Silva 2009, Hovinen ja Pyörälä 2011, Penev ym. 2012), eläinten käyttäytymiseen ja hyvinvointiin (DeVries ym. 2012, Ito ym. 2014), henkilökunnan turvallisuuteen (Kymäläinen ym. 2009) ja navetan pintamateriaalien sekä rakenteiden kestävyyteen (Mathiasson ym. 1991, De Belie ym. 2000).

Erilaisia mikrobiologisia, biokemiallisia, kemiallisia, fysikaalisia ja visuaalisia menetelmiä on käytetty pintapuhtauden tutkimiseen navettaympäristössä (Kymäläinen ym. 2009, Määttä ym. 2011). Pintapuhtausmenetelmiä valittaessa on otettava huomioon niiden sopivuus mittauksiin: osa menetelmistä soveltuu laboratoriotutkimuksiin ja osa kenttätutkimuksiin. Elintarviketeollisuuden hygieniakartoituksissa ovat esimerkiksi mikrobiologiset menetelmät ja pikamenetelmät hyvin yleisesti käytettyjä. Hygieniakartoituksia on tehty useassa eri ympäristössä, esimerkiksi teurastamoissa ja lihateollisuudessa (Suihko 
ym. 2002, Gudbjörnsdóttir ym. 2004), kalateollisuudessa (Miettinen ym. 2001), kasvisten jatkojalostusyrityksissä (Lehto ym. 2011, Kuisma ym. 2014) ja navetassa (Kymäläinen ja Kuisma 2014).

Kokonaismikrobimäärien selvittäminen on elintarviketeollisuuden yleisimmin käytetty pintojen yleishygienian mittausmenetelmä (Salo ym. 2000, Carrascosa ym. 2012). Usein tutkitaan myös homeita, hiivoja ja enterobakteereja. Aikaisemman tutkimuksen (Kymäläinen ja Kuisma 2014) tulokset osoittivat, että mikrobiologisia kontaktilevyjä voidaan käyttää navettarakennusten hygieniakartoituksissa. ATPbioluminesenssimenete0lmä on pikamenetelmä, joka mittaa näytteessä olevan ATP:n (adenosiinitrifosfaatti) määrän (Zutter ym. 1998, Lappalainen ym. 2000, Redsven ym. 2007). Menetelmä on laajasti käytetty omavalvonnassa ja hygieniatutkimuksissa. Eräät pikamenetelmät osoittavat pinnalla olevan proteiinia tai sokerin näytteenottovälineessä havaittavana värin muutoksena.

Esimerkiksi omavalvonnassa erilaiset liat todetaan erilaisten lian komponenttien yhdistelminä. Joissakin aikaisemmissa tutkimuksissa on raportoitu ruokajäämiä teräspinnoilla (esimerkiksi Moore ym. 2001), mutta tietoja erilaisista navettojen lioista ei ole aiemmin ollut saatavilla. Tämän laboratoriotutkimuksen tavoitteena oli tutkia eräiden tyypillisten navettojen likojen toteamista erilaisilla detektiomenetelmillä, kuten mikrobiologisilla kontaktilevyillä ja yleishygieniatesteillä. Tutkimusmenetelmät valittiin sillä periaatteella, että ne sopivat todellisiin olosuhteisiin ja kenttätutkimuksiin, ja lisäksi liat (epäpuhtaudet) valittiin edustamaan erilaisia tyypillisiä tai potentiaalisia aineita, joita esiintyy navettaympäristössä. Teräspinnat tutkittiin likaamisen jälkeen ja sen jälkeisen puhdistuksen jälkeen.

\section{Aineisto ja menetelmät}

Tutkittaviksi valittiin teräspinnat, joita on esimerkiksi navetoiden altaissa ja maitosäiliöissä. Pinnat liattiin seitsemällä erilaisella, navettaympäristölle tyypillisellä mallilialla, joita olivat neljä eri rehua (AIVrehu, rypsitiiviste, härkäpapu, porkkana), turvekuivike, lietelanta ja maito. Nestemäisessä muodossa olevia tai nestemuotoon saatettuja, homogenisoituja mallilikoja käsiteltiin erillisinä, vaikka todellisessa ympäristössä liat ovatkin usein erilaisia sekoituksia. Mallilioista mitattiin kuiva-ainepitoisuudet sekä mikrobimäärät (aerobiset mikrobit, homeet, hiivat, enterobakteerit), joita oli enimmillään noin $10^{6}$ $\mathrm{pmy} / \mathrm{ml}$ (pmy = pesäkkeen muodostava yksikkö).

Esipuhdistetun teräspinnan puhtaus mitattiin sekä ennen likausta että pinnan likauksen ja vakioidun puhdistuksen jälkeen. Pintapuhtaus mitattiin kuudella erilaisella mikrobiologisella kontaktilevyllä, kolmella eri proteiinitestillä, yhdellä glukoosi- ja laktoositestillä sekä ATP-bioluminesenssimenetelmää (ATP = adenosiinitrifosfaatti). Tulokset luokiteltiin puhtausluokkiin. Viidestä rinnakkaismittauksesta laskettiin keskiarvot ja -hajonnat. Tutkimusmenetelmät on kuvattu yksityiskohtaisesti lähdeartikkelissa (Kymäläinen ja Kuisma 2016).

\section{Tulokset ja tulosten tarkastelu}

Esipuhdistetuilla teräspinnoilla ei ollut havaittavia määriä mitään tässä tutkimuksessa tutkituista mikrobityypeistä (Taulukko 1). Vastaavasti proteiinia tai sokereita ei havaittu teräspinnoilta ennen likaamista (Taulukko 2). Pieniä ATP-määriä (15-23 RLU, keskiarvo 20 RLU; RLU = suhteellinen valoyksikkö) havaittiin esipuhdistetuista teräspinnoista (kuva 1), mutta kun nämä tulokset luokiteltiin menetelmäosassa esitetyllä tavalla, myös esipuhdistetun pinnan ATP-tulokset olisi luokiteltu hyviksi.

AIV-rehulla liatulta teräspinnalta todettiin aerobisia mikrobeja sekä likaamisen että puhdistuksen jälkeen ja pieni määrä hiivoja likaamisen jälkeen. Enterobakteereja ei havaittu (Taulukko 1). Proteiinia todettiin likaamisen jälkeen, mutta ei puhdistuksen jälkeen (Taulukko 2). ATP-määrät olivat erittäin suuret (keskiarvo $58400 \mathrm{RLU}$ ) liatuilla pinnoilla ja huomattavat (1040 RLU) myös puhdistuksen jälkeen (Kuva 1).

Kun teräspinta oli liattu rypsitiivisterehulla, todettiin useimpia mikrobeja. Puhdistuksen jälkeen vain yksi testi osoitti aerobisten mikrobien jäämiä (Taulukko 1). Likaamisen jälkeen kaikilla kolmella testillä 
havaittiin suuri määrä proteiinikontaminaatiota, ja puhdistuksen jälkeenkin kahdella testillä proteiinijäännöksiä (Taulukko 2). ATP-määrät olivat suuria (keskimäärin 1600 RLU) likaamisen jälkeen, mutta puhdistuksen jälkeen (38 RLU) tulokset olivat lähellä tausta-arvoa (20 RLU) (Kuva 1). Tulokset luokiteltiin kokonaisuutena huonoiksi likaamisen jälkeen ja hyviksi puhdistuksen jälkeen.

Kohtalaisia määriä aerobisia mikrobeja, koliformeja ja hiivoja todettiin rehulla liatulta teräspinnalta, ja puhdistuksen jälkeen pinnoilla oli yhä aerobisten mikrobien ja koliformien jäännöksiä. Enterobakteereja ei havaittu (Taulukko 1). Likaamisen jälkeen teräspinnalla havaittiin suuri määrä proteiineja ja hieman sokereita, mutta puhdistamisen jälkeen näitä epäpuhtauksia ei todettu (Taulukko 2). ATP-määrät olivat kohtalaisia sekä likaamisen (keskiarvo 86 RLU) että puhdistuksen jälkeen (68 RLU) (Kuva 1).

Taulukko 1. Teräspintojen mikrobimäärät likaamisen ja puhdistamisen jälkeen

\begin{tabular}{|c|c|c|c|c|c|c|c|c|c|c|c|c|}
\hline \multirow{3}{*}{ Liat } & \multirow{3}{*}{$\begin{array}{l}\text { Tutkittavan } \\
\text { pinnan tila }\end{array}$} & \multicolumn{11}{|c|}{ Tutkimusmenetelmä* } \\
\hline & & \multicolumn{3}{|c|}{ Aerobiset mikrobit } & \multicolumn{2}{|c|}{ Enterobakteerit } & \multirow{2}{*}{$\frac{\beta \text {-gur }}{\text { (M2) }}$} & \multirow{2}{*}{$\begin{array}{l}\text { Koliformit } \\
\text { (M5) }\end{array}$} & \multicolumn{2}{|c|}{ Homeet } & \multicolumn{2}{|l|}{ Hiivat } \\
\hline & & (M1) & (M4) & (M5) & (M2) & (M4) & & & (M3) & (M6) & (M3) & (M6) \\
\hline ' & $\begin{array}{l}\text { Ennen } \\
\text { likausta }\end{array}$ & 0 & 0 & 0 & 0 & 0 & 0 & 0 & - & - & 0 & 0 \\
\hline \multirow{2}{*}{ 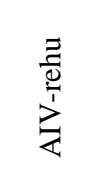 } & Liattu & $\begin{array}{l}80 \\
(0)\end{array}$ & $\begin{array}{l}1,9 \\
(0,5)\end{array}$ & $\begin{array}{l}40 \\
(0)\end{array}$ & 0 & 0 & 0 & 0 & - & - & $\begin{array}{l}0,1 \\
(0,2)\end{array}$ & 0 \\
\hline & Puhdistettu & $\begin{array}{l}3,4 \\
(1,8)\end{array}$ & $\begin{array}{l}4,0 \\
(0,3)\end{array}$ & 0 & 0 & 0 & 0 & 0 & - & - & 0 & 0 \\
\hline \multirow{2}{*}{ 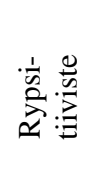 } & Liattu & $\begin{array}{l}1,7 \\
(0,9)\end{array}$ & $\begin{array}{l}2,5 \\
(0,4)\end{array}$ & $\begin{array}{l}0,3 \\
(0,4)\end{array}$ & $\begin{array}{l}0,1 \\
(0,2)\end{array}$ & $\begin{array}{l}1,2 \\
(1,6)\end{array}$ & $\begin{array}{l}0,0 \\
(0,1)\end{array}$ & $\begin{array}{l}0,0 \\
(0,4)\end{array}$ & - & - & $\begin{array}{l}1,1 \\
(0,8)\end{array}$ & $\begin{array}{l}0,3 \\
(0,5)\end{array}$ \\
\hline & Puhdistettu & 0 & $\begin{array}{l}0,2 \\
(0,3)\end{array}$ & 0 & 0 & 0 & 0 & 0 & - & - & 0 & 0 \\
\hline \multirow{2}{*}{$\begin{array}{l}\vec{Q} \\
\widetilde{2}\end{array}$} & Liattu & $\begin{array}{l}2,0 \\
(1,0)\end{array}$ & $\begin{array}{l}2,0 \\
(0,8)\end{array}$ & $\begin{array}{l}0,0 \\
(0,0)\end{array}$ & 0 & 0 & 0 & $\begin{array}{l}0,0 \\
(0,0)\end{array}$ & - & - & 0 & $\begin{array}{l}1,7 \\
(1,0)\end{array}$ \\
\hline & Puhdistettu & 0 & $\begin{array}{l}0,1 \\
(0,1)\end{array}$ & 0 & 0 & 0 & 0 & $\begin{array}{l}0,1 \\
(0,2)\end{array}$ & - & - & 0 & 0 \\
\hline \multirow{2}{*}{ 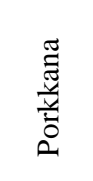 } & Liattu & $\begin{array}{l}3,7 \\
(1,2)\end{array}$ & $\begin{array}{l}5,7 * \\
(4,3)\end{array}$ & $\begin{array}{l}2,0 \\
(0,6)\end{array}$ & $\begin{array}{l}4,4 \\
(1,3)\end{array}$ & $\begin{array}{l}2,0 * * \\
(0,5)\end{array}$ & $\begin{array}{l}3,4 \\
(2,2)\end{array}$ & $\begin{array}{l}0,5 \\
(0,4)\end{array}$ & - & - & $\begin{array}{l}2,4 \\
(1,8)\end{array}$ & $\begin{array}{l}8,2 \\
(5,2)\end{array}$ \\
\hline & Puhdistettu & $\begin{array}{l}0,2 \\
(0,0)\end{array}$ & $\begin{array}{l}0,2 \\
(0,2)\end{array}$ & $\begin{array}{l}0,0 \\
(0,0)\end{array}$ & 0 & $\begin{array}{l}0,0 \\
(0,0)\end{array}$ & 0 & 0 & - & - & 0 & 0 \\
\hline \multirow{2}{*}{ 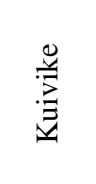 } & Liattu & $\begin{array}{l}45 \\
(0)\end{array}$ & $\begin{array}{l}12 \\
(0)\end{array}$ & $\begin{array}{l}12 \\
(0)\end{array}$ & 0 & $\begin{array}{l}7,5 \\
(6,2)\end{array}$ & 0 & 0 & - & - & $\begin{array}{l}29 \\
(22)\end{array}$ & $\begin{array}{l}2,5 \\
(0)\end{array}$ \\
\hline & Puhdistettu & $\begin{array}{l}0,5 \\
(0,3)\end{array}$ & $\begin{array}{l}0,6 \\
(1,1)\end{array}$ & 0 & 0 & $\begin{array}{l}0,0 \\
(0,0)\end{array}$ & 0 & 0 & - & - & $\begin{array}{l}0,1 \\
(0,1)\end{array}$ & 0 \\
\hline \multirow{2}{*}{ 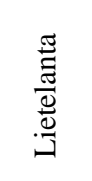 } & Liattu & $\begin{array}{l}45 \\
(0)\end{array}$ & $\begin{array}{l}12 \\
(0)\end{array}$ & $\begin{array}{l}12 \\
(0)\end{array}$ & $\begin{array}{l}1,3 \\
(1,0)\end{array}$ & $\begin{array}{l}2,6 \\
(1,2)\end{array}$ & $\begin{array}{l}0,7 \\
(0,4)\end{array}$ & $\begin{array}{l}0,3 \\
(0,3)\end{array}$ & $\begin{array}{l}+++ \\
(0)\end{array}$ & $\begin{array}{l}+++ \\
(0)\end{array}$ & $\begin{array}{l}29 \\
(22)\end{array}$ & $\begin{array}{l}2,5 \\
(0)\end{array}$ \\
\hline & Puhdistettu & $\begin{array}{l}4,7 \\
(1,3)\end{array}$ & $\begin{array}{l}1,7 \\
(0,6)\end{array}$ & $\begin{array}{l}1,6 \\
(0,7)\end{array}$ & $\begin{array}{l}0,0 \\
(0,1)\end{array}$ & 0 & 0 & $\begin{array}{l}0,6 \\
(0,5)\end{array}$ & - & $\begin{array}{l}+ \\
(+)\end{array}$ & 0 & 0 \\
\hline \multirow{2}{*}{ 党 } & Liattu & 0 & 0 & 0 & 0 & 0 & 0 & 0 & - & - & 0 & 0 \\
\hline & Puhdistettu & 0 & 0 & 0 & 0 & 0 & 0 & 0 & - & - & 0 & 0 \\
\hline
\end{tabular}

*Kontaktilevyjen koodit: (M1) aerobiset mikrobit, (M2) enterobakteerit/ ß-glukuronidaasipositiiviset organismit, (M3) hiivat ja homeet, (M4) kokonaisbakteerit/enterobakteerit, (M5) aerobiset bakteerit ja koliformit ja (M6) hiivat ja homeet; **neljän rinnakkaiskokeen keskiarvo. 
Taulukko 2. Eri detektiomenetelmillä todetut malliliat teräspinnalla ennen pinnan puhdistusta ja sen jälkeen.

\begin{tabular}{|c|c|c|c|c|c|c|c|c|}
\hline \multirow[t]{3}{*}{ Liat } & \multicolumn{6}{|c|}{ Proteiinitestit* } & \multirow{2}{*}{\multicolumn{2}{|c|}{$\begin{array}{c}\text { Sokeritesti** } \\
\text { SpotCheck }\end{array}$}} \\
\hline & \multicolumn{2}{|r|}{ Clean Card } & \multicolumn{2}{|c|}{ Pro Clean } & \multicolumn{2}{|c|}{ Clean Trace } & & \\
\hline & Liattu & Puhdistettu & Liattu & Puhdistettu & Liattu & Puhdistettu & Liattu & Puhdistettu \\
\hline Ennen likausta & & 0 & & 0 & & 0 & & 0 \\
\hline AIV-rehu & $\mathrm{X}$ & 0 & $\mathrm{X}$ & 0 & $\mathrm{X}$ & 0 & 0 & 0 \\
\hline Rypsitiiviste & $\mathrm{XX}$ & $\mathrm{X}$ & $\mathrm{XX}$ & 0 & XX & $\mathrm{X}^{* * *}$ & 0 & 0 \\
\hline Rehu & $\mathrm{XX}$ & 0 & $\mathrm{XX}$ & 0 & $\mathrm{XX}$ & 0 & $\mathrm{X}$ & 0 \\
\hline Porkkana & $\mathrm{XX}$ & 0 & $\mathrm{XX}$ & 0 & $\mathrm{X}$ & 0 & $\mathrm{X}$ & 0 \\
\hline Kuivike & 0 & 0 & 0 & 0 & 0 & 0 & 0 & 0 \\
\hline Lietelanta & - & - & $\mathrm{XX}$ & $\mathrm{X}$ & $\mathrm{XX}$ & $\mathrm{X}$ & 0 & 0 \\
\hline Maito & $\mathrm{XX}$ & $\mathrm{XX}$ & $\mathrm{XX}$ & $\mathrm{X}$ & $\mathrm{XX}$ & $X$ & 0 & 0 \\
\hline
\end{tabular}

- Lian värin takia mittausta ei voitu tehdä; *proteiinitestin vaihteluväli: 0 likaa ei havaittu, $\mathrm{x}$ likaa havaittiin vähän, xx likaa havaittiin paljon; **sokeritestin vaihteluväli: 0 likaa ei havaittu, x likaa havaittiin; ***viiden rinnakkaiskokeen vaihteluväli $0-\mathrm{x}$.

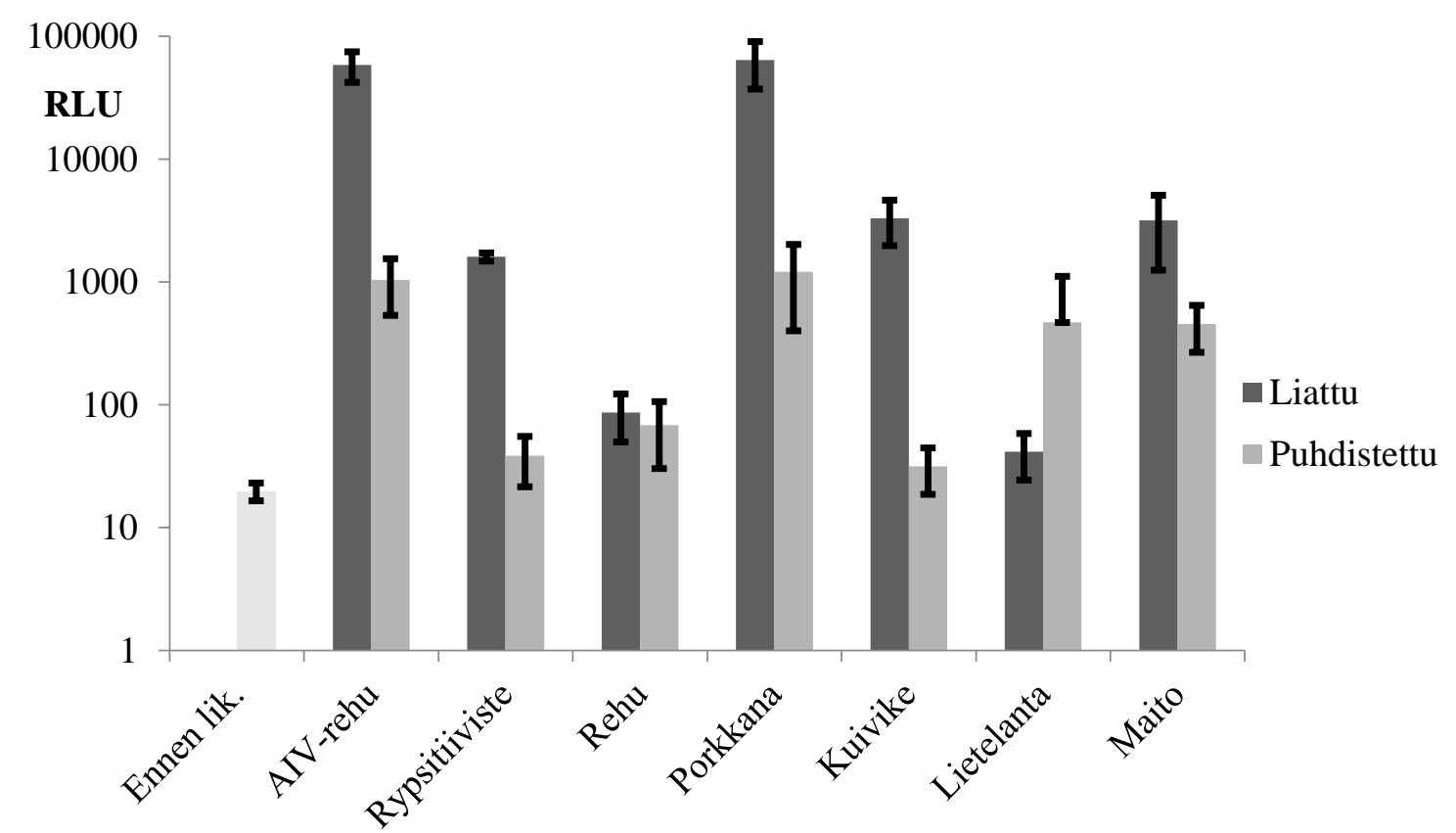

Kuva 1. Teräspinnan puhtaus likauksen ja puhdistuksen jälkeen mitattuna ATP-bioluminesenssimenetelmällä. Tulokset ovat suhteellisina valoyksiköinä (RLU, relative light unit); pylväs = viiden mittauksen keskiarvo, jana = keskihajonta

Porkkanamehulla liatuilta pinnoilta todettiin kaikkia tutkittavia mikrobeja paitsi hiivoja. Puhdistuksen jälkeen havaittiin pieniä määriä aerobisia mikrobeja ja enterobakteereita (Taulukko 1). Likaamisen jälkeen pinnalla todettiin kaikilla proteiinitesteillä suuri määrä tai ainakin hieman proteiinikontaminaatiota, ja myös sokereita havaittiin, mutta puhdistamisen jälkeen näitä epäpuhtauksia ei havaittu (Taulukko 2). Porkkanalian ATP-määrät olivat samankaltaiset kuin AIV-rehun tulokset: erittäin suuret (keskimäärin 63800 RLU) likaamisen jälkeen ja edelleen merkittävät (1300 RLU) puhdistuksen jälkeen (Kuva 1).

Teräspinnalla havaittiin suuria määriä aerobisia mikrobeja, enterobakteereja (yhdellä testillä), $\beta$-glukuronidaasi-positiivisia organismeja ja hiivoja sen jälkeen, kun pinnat oli liattu kuivikelialla. Puhdistuksen jälkeen kaikkien näiden mikrobien jäämiä oli edelleen havaittavia (Taulukko 1). Proteiinia ja sokereita ei todettu likaamisen ja puhdistuksen jälkeen (Taulukko 2). ATP-määrät olivat suuret likaamisen jälkeen (3300 RLU), mutta lähellä tausta-arvoa puhdistuksen jälkeen (32 RLU) (Kuva 1). 
Lietelannalla liatut teräspinnat sisälsivät kaikkia tutkittavia mikrobeja. Puhdistuksen jälkeen $\beta$-glukuronidaasipositiivisia mikrobeja ei havaittu ja enterobakteerien määrä oli erittäin pieni, kun taas kaikkia muita mikrobeja todettiin (Taulukko 1). Likaamisen jälkeen pinnalta havaittiin runsaasti ja puhdistuksen jälkeen hieman proteiinia (Taulukko 2). Proteiinitesti P1 ei toiminut kunnolla puhdistuksen jälkeen lietelannan tumman värin vuoksi. Likaamisen jälkeen havaittiin vain alhaisia ATP-tasoja (41 RLU), kun taas puhdistamisen jälkeen luvut olivat selvästi suuremmat (467 RLU) (kuva 1).

Poikkeuksena kaikista muista tutkituista lioista maitoa ei tuottanut millään mikrobitestillä vastetta (Taulukko 1). Sen sijaan maidolla liatulta pinnalta todettiin suuri määrä proteiinia likaamisen jälkeen ja ainakin jonkin verran puhdistuksen jälkeen (Taulukko 2). Maidolla likaamisen jälkeen pinnan ATP-määrä (3160 RLU) oli samankaltainen kuin kuivikkeella ja rypsitiivisteellä liatuilla pinnoilla; puhdistamisen jälkeen maidolla liatun pinnan tulos (456 RLU) oli samaa tasoa kuin lietelannalla liatulla pinnalla (Kuva 1).

Erilaiset hygieniatestit on kehitetty mittaamaan erilaisia kontaminantteja ja likoja. Tässäkin navetan likoihin keskittyvässä tutkimuksessa korrelaatiot eri mittausmenetelmien tulosten välillä olivat pääosin heikkoja. Esimerkiksi aerobisten mikrobien sekä proteiinitestin ja ATP-bioluminesenssimittauksen tulosten välillä ei todettu korrelaatiota. Aerobisten mikrobien tulosten välinen korrelaatiokerroin (r) eri valmistajien kontaktilevyillä saatujen tulosten välillä vaihteli 0,45 :stä 0,68 :een $(\mathrm{p}<0,001)$. Tyypillisesti etenkin tutkimushankkeissa käytetään useita, toisiaan täydentäviä pintahygienian mittausmenetelmiä. Käytännön omavalvontaan valitaan parhaiten soveltuva menetelmä.

\section{Johtopäätökset}

Samaa likaakaan mittaavat menetelmät eivät aina tuota yhteneväisiä tuloksia, joten esimerkiksi omavalvonnassa tulee verrata vain yhden menetelmän tai laitteen tuloksia keskenään. Suurin korrelaatio todettiin tässä tutkimuksessa kolmen eri proteiinitestin tulosten välillä. Yhteys havaittiin myös tiettyjen, samaan mikrobiryhmään kohdistuvien kontaktilevymittausten tulosten välillä, mutta havainto ei pätenyt kaikkiin tutkittuihin kontaktilevyihin.

Eräs tutkimuksen keskeinen tulos oli, että suurinta osaa menetelmistä voitaisiin käyttää navettaympäristön tilojen pintapuhtauden mittaamisessa. Sokeritesti mittasi huonoiten testattuja navetan mallilikoja. Menetelmien vaste eri likoihin oli kuitenkin hyvin erilainen, joten tulosten perusteella ei voida nimetä yksielitteisesti parasta menetelmää jokaiseen tilaan. Tulee siis arvioida, onko keskeinen likatyyppi ja mittausintressi esimerkiksi mikrobiologinen kontaminaatio, proteiinilika jne. Lian värillisyys vaikuttaa menetelmissä, joissa puhtaustulosta arvioidaan mittavälineen värin muutoksena, kuten esimerkiksi proteiinitesteissä. Näytteenottokohteiden ja -ajankohtien valinnalla vaikutetaan paljon hygieniamittausten tuloksiin. Koska navettaympäristön pintahygienialle ei ole olemassa yleisiä raja-arvoja, tulosten käsittely, arviointi, luokittelu ja tulkinta vaikuttavat merkittävästi tutkimuksesta tehtäviin päätelmiin. Tämän tutkimuksen tulokset auttavat valitsemaan hygienian mittausmenetelmiä navettaympäristöön ja tiloihin, joissa voi olla navetalle tyypillisiä likoja.

\section{Kirjallisuus}

Carrascosa, C., Saavedra, P., Millan, R., Jaber, J. R., Perez, E., Grau, R., Raposo, A., Mauricio, C. \& Sanjuan, E. 2012. Monitoring of cleanliness and disinfection in dairies: Comparison of traditional microbiological and ATP bioluminescence methods. Food Control 28: 368-373.

De Belie, N., Richardson, M., Braam, C. R., Svennerstedt, B., Lenehan, J.J. \& Sonck, B. 2000. Durability of building materials and components in the agricultural environment, Part I: The agricultural environment and timber structures. Journal of Agricultural Engineering Research 75: 225-241.

De Koning, K., Slaghuis, B. \& van der Vorst, Y. 2003. Robotic milking and milk quality: effects on bacterial counts, somatic cell counts, freezing points and free fatty acids. Italian Journal of Animal Science 2: 291-299.

DeVries, T. J., Aarnoudse, M. G., Barkema, H. W., Leslie, K. E. \& von Keyserlingk, M. A. G. 2012. Associations of dairy cow behavior, barn hygiene, cow hygiene, and risk of elevated somatic cell count. Journal of Dairy Science 95: 5730-5739. 
Gudbjörnsdóttir, B., Suihko, M.L., Gustavsson, P., Thorkelsson, G., Salo, S., Sjöberg, A.M., Niclasen, O. \& Bredholt, S. 2004. The incidence of Listeria monocytogenes in meat, poultry and seafood plants in the Nordic countries. Food Microbiology 21: 217-225.

Hanus, O., Frelich, J., Vyletelova, M., Roubal, P., Vorlicek, Z. \& Jedelska, R. 2004. Technologically difficult, pathogenic and food risky bacterial contamination of raw milk and other materials from dairy cow herds. Czech Journal of Animal Science 49: 489-499.

Ito, K., Chapinal, N., Weary, D.M. \& von Keyserlingk. M.A.G. 2014. Associations between herd-level factors and lying behavior of freestall-housed dairy cows. Journal of Dairy Science 97: 2081-2089.

Kuisma, R., Pienmunne, E., Lehto, M. \& Kymäläinen, H.-R. 2014. Surface hygiene in vegetable processing plants: Results of a repeated hygiene survey. Journal of Hygienic Engineering and Design 7: 51-58.

Kuisma, R. \& Kymäläinen, H.-R. 2017. Pintahygienian detektointimenetelmien toimivuus maidontuotantoympäristössä. Elintarvike ja terveys 31: 12-15.

Kymäläinen, H.-R. \& Kuisma, R. 2016. Detection methods for cleanness in cattle barns. Agricultural Engineering International: CIGR Journal 18: 11-24.

Kymäläinen, H.-R. \& Kuisma, R. 2014. Hygiene of environmental surfaces in a cattle barn. Agricultural Engineering International: CIGR Journal 16: 45-54.

Kymäläinen, H.-R., Kuisma, R. Määttä, J. \& Sjöberg, A.-M. 2009. Assessment of cleanness of environmental surfaces in cattle barns and piggeries: A review. Agricultural and Food Science 18: 268-282.

Lappalainen, J., Loikkanen, S., Havana, M. Karp, M., Sjöberg, A.-M. \& Wirtanen, G. 2000. Microbial testing methods for detection of residual cleaning agents and disinfectants - prevention of ATP bioluminescence measurement errors in the food industry. Journal of Food Protection 63: 210-215.

Lehto, M., Kuisma, R., Määttä, J., Kymäläinen, H.-R. \& Mäki, M. 2011. Hygienic level and surface contamination in fresh-cut vegetable production plants. Food Control 22: 469-475.

Mathiasson, L., Knutsson, M., Bremle, G. \& Mårtensson, L. 1991. Chemical environment in animal buildings. Swedish Journal of Agricultural Research 21: 147-155.

Miettinen, H., Aarnisalo, K., Salo, S. \& Sjöberg, A.-M. 2001. Evaluation of surface contamination and the presence of Listeria monocytogenes in fish processing Factories. The Journal of Food Protection 64: 635-639.

Moore, G., Griffith,C. \& Fielding, L. 2001. A comparison of traditional and recently developed methods for monitoring surface hygiene within the food industry: a laboratory study. Dairy, Food and Environmental Sanitation 21: 478-488.

Noordhuizen, J. P. \& Cannas da Silva, J. 2009. Animal hygiene and animal health in dairy cattle operations. The Open Veterinary Science Journal 3: 17-21.

Redsven, I., Kymäläinen, H.-R., Pesonen-Leinonen, E., Kuisma, R., Ojala-Paloposki, T., Hautala, M. \& Sjöberg, A.-M. 2007. Evaluation of a bioluminescence method, contact angle measurements and topography for testing the cleanability of plastic surfaces under laboratory conditions. Applied Surface Science 253: 5536-5543.

Salo, S., Laine, A., Alanko, T., Sjöberg, A.-M. \&Wirtanen, G. 2000. Validation of the microbiological methods Hygicult dipslide, contact plate, and swabbing in surface hygiene control: A Nordic collaborative study. Journal of JAOAC International 83: 1357-1365.

Skrzypek, R. 2006. Factors affecting somatic cell count and total microorganisms count in cow's milk. Polish Journal of Food and Nutrition Sciences 15: 209-213.

Suihko, M.-L., Salo, S., Niclasen, O., Gudbjörnsdóttir, B., Torkelsson, G., Bredholt, S., Sjöberg, A.-M. \& Gustavsson, P. 2002. Characterization of Listeria monocytogenes isolates from the meat, poultry and seafood industries by automated ribotyping. International Journal of Food Microbiology 72: 137-146.

Trevisi, E., Bionaz, M., Piccioli-Cappelli, F. \& Bertoni, G. 2006. The management of intensive dairy farms can be improved for better welfare and milk yield. Livestock Science 103: 231-236.

Zutter, de L., Hellwig, K. \& Linhhardt, C. 1998. Outstanding applicability of ATP method as hygiene monitoring to reveal hidden potential for microbial product contamination, demonstrated in practical situations after cleaning. Dutch original De Keurmeester 3: 5-10. 